\title{
Vanadate Normalizes Hyperglycemia in Two Mouse Models of Non-insulin-dependent Diabetes Mellitus
}

Joseph Meyerovitch, Paul Rothenberg, Yoram Shechter, Susan Bonner-Weir, and C. Ronald Kahn

Research Division, Joslin Diabetes Center, Department of Medicine, Brigham and Women's Hospital, and Harvard Medical School, Boston, Massachusetts 02215

\begin{abstract}
We have studied the effects of oral administration of vanadate, an insulinometic agent and a potent inhibitor of phosphotyrosyl protein phosphatase (PTPase) in vitro, on blood glucose and PTPase action, in two hyperinsulinemic rodent models of noninsulin-dependent diabetes mellitus (NIDDM). Oral administration of vanadate $(0.25 \mathrm{mg} / \mathrm{ml}$ in the drinking water) to ob/ob mice for 3 wk lowered blood glucose level from $236 \pm 4$ to $143 \pm 2$ $\mathrm{mg} / \mathrm{dl}$ without effect on body weight. Administration of vanadate to $\mathrm{db} / \mathrm{db}$ mice produced a similar effect. Electron microscopic examination revealed no signs of hepatotoxicity after 47 d of treatment.

There was a slight reduction in insulin receptor autophosphorylation when tested by immunoblotting with antiphosphotyrosine antibody after in vivo stimulation, and the phosphorylation of the endogenous substrate of the insulin receptor, pp185, was markedly decreased in the ob/ob mice. Both cytosolic and particulate PTPase activities in liver of ob/ob mice measured by dephosphorylation of a ${ }^{32} \mathbf{P}$-labeled peptide corresponding to the major site of insulin receptor autophosphorylation were decreased by $\sim 50 \%(P<0.01)$. In $\mathrm{db} / \mathrm{db}$ diabetic mice, PTPase activity in the cytosolic fraction was decreased to $53 \%$ of control values $(P<0.02)$ with no significant difference in the particulate PTPase activity. Treatment with vanadate did not alter hepatic PTPase activity as assayed in vitro, or receptor and substrate phosphorylation as assayed in vivo, in ob/ob mice despite its substantial effect on blood glucose. These data indicate that vanadate is an effective oral hypoglycemic treatment in NIDDM states and suggest that its major effects occurs distal to the insulin receptor tyrosine kinase. (J. Clin. Invest. 1991. 87:1286-1294.) Key words: insulin action • insulin receptor kinase • tyrosine phosphorylation • diabetes mellitus therapy
\end{abstract}

\section{Introduction}

Insulin and other growth factor receptors possess intrinsic tyrosine kinase activity (1). The binding of insulin to its receptor

Address correspondence to C. Ronald Kahn, M.D., Joslin Diabetes Center, One Joslin Place, Boston, MA 02215. Dr. Meyerovitch's current address is Institute of Pediatric and Adolescence Endocrinology, Beilinson Medical Center, Petah Tikva 49100 Israel. Dr. Shechter's current address is The Weizmann Institute of Science, Department of Hormone Research, Rehovot 76100 Israel.

Received for publication 15 February 1990 and in revised form 5 December 1990.

J. Clin. Invest.

(c) The American Society for Clinical Investigation, Inc.

0021-9738/91/04/1286/09 \$2.00

Volume 87, April 1991, 1286-1294 induces rapid autophosphorylation of the receptor which activates the tyrosine protein kinase activity towards several cellular substrates for the receptor (reviewed in reference 2). Dephosphorylation of the insulin receptor inactivates it $(3,4)$. Based on several lines of evidence, it had been suggested that kinase activity is essential for some or all of the effects of insulin $(5,6)$.

Vanadate is a trace element which has been shown to be a potent insulinomimetic agent in isolated adipocytes (reviewed in reference 7). In streptozotocin (STZ) ${ }^{1}$ treated diabetic rats, vanadate normalizes blood glucose $(8,9)$ and restores liver 6phosphofructose-2-kinase glucokinase activity toward normal (10). Vanadate has been shown to be a potent inhibitor of phosphotyrosyl protein phosphatase (PTPase) activity in vitro at concentrations which do not inhibit phosphoserine and phosphothreonine phosphatase activity $(11,12)$. Under certain conditions, vanadate may also directly stimulate $\beta$-subunit tyrosine autophosphorylation and in vitro phosphotransferase activity of purified insulin receptors (13), but this action has not been observed in all studies (14). Vanadate increases glucose transport in trypsin-treated adipocytes and in cells where the insulin receptor concentration is reduced $60 \%$ by receptor downregulation (15), suggesting a postreceptor mechanism of vanadate action.

Two well-studied rodent models of type II diabetes are ob/ $\mathrm{ob}$ and $\mathrm{db} / \mathrm{db}$ mice. These homozygous mice are characterized by obesity, hyperglycemia, hyperinsulinemia, and a blunted response to insulin at the receptor and postreceptor levels (1626). The exact etiology of the two syndromes has not been elucidated, although several glycolytic and gluconeogenic enzymes are elevated in the livers of these animals (16-26). Both models demonstrate several metabolic defects consistent with peripheral insulin insensitivity, including decreased binding to liver plasma membranes and hepatocytes (21), increased nonsuppressible gluconeogenesis $(19,22)$ and failure of exogenous insulin to ameliorate the syndrome (19). In spite of the decreased number of insulin receptors in the ob/ob and $\mathrm{db} / \mathrm{db}$ mice, the kinase activity per receptor had been reported to be normal (23, 24; Yamada, K., et al., unpublished observation). However, in one study the insulin receptor kinase in the muscle of ob/ob mice was reported to be defective (25). We have previously reported that vanadate normalized blood glucose in two models of insulin-deficient diabetes in rats, and that this was associated with a lowering of elevated PTPase activity present in particulate fractions of liver (26). In this study, we have investigated whether hepatic PTPase activity is altered in rodent models of non-insulin-dependent diabetes mellitus

1. Abbreviations used in this paper: NIDDM, non-insulin-dependent diabetes mellitus; PTPase, phosphotyrosyl protein phosphatase; STZ, streptozotocin; WGA, wheat germ agglutinin 
(NIDDM) and whether vanadate administration normalizes the hyperglycemia. In addition, we have evaluated the effect of vanadate administration on diabetes-related changes in PTPase activity, insulin receptor binding, and the phosphorylation state of the receptor $\beta$-subunit and its putative endogenous substrate, $\mathrm{pp} 185$, in vivo.

\section{Methods}

\section{Materials}

$\left[\gamma^{32} \mathrm{P}\right] \mathrm{ATP}(3,000 \mathrm{Ci} / \mathrm{mmol})$ was obtained from New England Nuclear (Boston, MA); wheat germ agglutinin agarose (WGA) was from Vector Laboratories, Inc. (Burlingame, CA); sodium orthovanadate was from Aldrich Chemical Company, Inc. (Milwaukee, WI). Streptozotocin, Hepes, phenylmethylsulfonyl fluoride (PMSF), $N^{\alpha}$ - $P$-tosyl-L-lysine chlormethyl ketone (TLCK), $N^{\alpha}$-tosyl-l-phenylalanine chloromethyl ketone (TPCK), aprotinin, $N$-acetyl-D-glucosamine were from Sigma Chemical Co. (St. Louis, MO). Silicotungstic acid was from J. T. Baker Chemical Co. (Phillipsburg, NJ). Dithiothreitol (DTT), Coomassie blue Triton X-100, and AG 1-X2 acetate were purchased from BioRad Laboratories, Inc. (Richmond, CA). The synthetic peptide, ThrArg-Asp-Ile-Tyr-Glu-Thr-Asp-Tyr-Tyr-Arg-Lys, which contains the amino acid sequence between residues 1142 and 1153 of the insulin receptor $\beta$-subunits (27) was purchased from Dr. David Coy, Tulane University (New Orleans, LA). 3-[(3-Cholamidopropyl)dimethylammonio]-2-hydroxyl-1-propanesulfonate (CHAPSO) was purchased from Pierce Chemicals (Rockford, IL).

\section{Animals}

Female obese-hyperglycemic mice (C57B1/6J ob/ob) and the obese diabetic mice (C57B / / KsJ db/db) and their lean matched controls (ob/ $+)$ and $(\mathrm{db} /+)$ were purchased from Jackson Laboratory (Bar Harbor, ME) and used at 6-8 wk of age. Mice were fed ad libitum a standard laboratory chow. The fed mice were anesthetized by ether and then bled through the orbital venous plexus. Venous blood and liver samples were taken between 9 and 11 a.m. As noted in the figure legends and text, some mice were treated with vanadate $(0.25 \mathrm{mg} / \mathrm{ml})$ included in the drinking water. $80 \mathrm{mM} \mathrm{NaCl}$ was also included to reduce vanadate toxicity, as previously described $(8,9)$. For these experiments, control mice were treated with $80 \mathrm{mM} \mathrm{NaCl}$ alone.

\section{Methods}

Preparations of ${ }^{32}$ P-labeled peptide 1142-1153. Wheat germ agglutinin purified insulin receptor (28) was incubated with $100 \mathrm{nM}$ insulin for 30 min at $4^{\circ} \mathrm{C}$, after which $100 \mu \mathrm{M}\left[\gamma_{-}-{ }^{32} \mathrm{P}\right] \mathrm{ATP}$ (sp act $14.2 \mathrm{Ci} / \mathrm{mol}$ ), 5

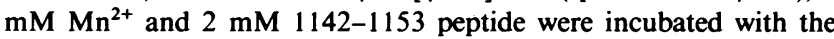
receptor overnight at $4{ }^{\circ} \mathrm{C}$. ${ }^{32} \mathrm{P}$-Peptide was separated from ${ }^{32} \mathrm{P}$-ATP by chromatography on AG 1-X2 acetate column (29) and on a C-18 SEPPAK cartridge (Waters Associates, Milford, MA) and lyophilized.

Tissue extraction. Mice were sacrificed by cervical dislocation, and livers were rapidly removed. All tissue extractions were performed at $4^{\circ} \mathrm{C}$. Livers were homogenized using a Potter-Elvejhem type homogenizer rotating at $1,300 \mathrm{rpm}$ for $20 \mathrm{~s}$ in 3 vol of buffer A $(20 \mathrm{mM}$ Tris$\mathrm{HCl}, \mathrm{pH}$ 7.5, $50 \mathrm{mM}$ 2-mercaptoethanol, $250 \mathrm{mM}$ sucrose, $2 \mathrm{mM}$ EDTA, $10 \mathrm{mM}$ EGTA, $10 \mu \mathrm{g} / \mathrm{ml}$ aprotinin, $25 \mu \mathrm{g} / \mathrm{ml}$ leupeptin, 0.1 $\mathrm{mM}$ TLCK, $0.1 \mathrm{mM}$ TPCK, $0.5 \mathrm{mM}$ benzamidine, $0.2 \mathrm{mM}$ phenylmethylsulfonyl fluoride, and $5 \mu \mathrm{g} / \mathrm{ml}$ each of pepstatin $\mathrm{A}$, antipain, and chymostatin). Homogenates were centrifuged at $10,000 \mathrm{~g}$ for $20 \mathrm{~min}$, and the supernatant was further centrifuged at $100,000 \mathrm{~g}$ for $45 \mathrm{~min}$. The final supernatant was designated the cytosolic fraction. The pellet resulting from the $100,000 \mathrm{~g}$ spin was solubilized using a Potter-Elvejhem type homogenizer rotating at $1,300 \mathrm{rpm}$ for $5 \mathrm{~min}$ in buffer $\mathrm{A}$ containing $1 \%(\mathrm{wt} / \mathrm{vol}) \mathrm{CHAPSO}$ and was then centrifuged $45 \mathrm{~min}$ at $100,000 \mathrm{~g}$ to remove insoluble material. The solubilized material in the supernatant was designated the particulate fraction. In some experiments, this fraction was further fractionated by chromatography on
WGA-agarose columns. After application, the column was washed with 50 bed volumes of $10 \mathrm{mM}$ Hepes buffer, $\mathrm{pH} \mathrm{7.6,0.1 \%} \mathrm{(vol/vol)}$ Triton 100, $5 \mathrm{mM}$ EDTA, $0.5 \mathrm{mM}$ benzamidine, $0.2 \mathrm{mM}$ PMSF, and $0.1 \%$ (vol/vol) 2-mercaptoethanol (buffer B) and eluted with two bed volumes with $0.3 \mathrm{M} \mathrm{N}$-acetyl glucosamine in buffer $\mathrm{B}$. The WGA-purified fractions were designated the glucoprotein-enriched fractions. All preparations were stored at $-70^{\circ} \mathrm{C}$ before use.

PTPase assays. The dephosphorylation reaction was carried out at $30^{\circ} \mathrm{C}$ in a final volume of $50 \mu \mathrm{l}$ of $50 \mathrm{mM}$ Hepes, $\mathrm{pH} \mathrm{7.0,2} \mathrm{mM} \mathrm{EDTA,}$ and $1 \mathrm{mM}$ DTT, and was terminated by the addition of $30 \mu 110 \%$ TCA and $20 \mu 11 \%(w t / v o l)$ BSA. After incubation at $4^{\circ} \mathrm{C}$ for $10 \mathrm{~min}$ and centrifugation to remove precipitated proteins, ${ }^{32} \mathrm{P}_{\mathrm{i}}$ released from ${ }^{32} \mathrm{P}$ peptide was measured using organic extraction of $P_{i}(30)$. Reaction rates were linear when under $20 \%$ of the phosphate was released from the peptide; therefore, the extent of dephosphorylation was kept within this limit. Concentrations of phosphotyrosyl peptide were calculated from the ${ }^{32} \mathrm{P}$ content and the specific activity of $\left[\gamma-{ }^{32} \mathrm{P}\right] \mathrm{ATP}$. Specific PTPase activity was defined as the amount of enzyme hydrolyzing 1 pmol phosphate/min per mg protein.

${ }^{125}$ I-Insulin binding to solubilized insulin receptor. An insulin receptor preparation was prepared as previously described (28) and diluted in $50 \mathrm{mM}$ Hepes, $\mathrm{pH} 7.6,0.1 \%$ Triton X-100. Aliquots $(5-9 \mu \mathrm{g}$ protein) of WGA eluate were incubated with ${ }^{125} \mathrm{I}$-insulin $(0.1 \mathrm{ng} / \mathrm{ml}$, $2,000 \mathrm{Ci} / \mathrm{mmol}$ ) in the absence or presence of $1 \mu \mathrm{mol}$ unlabeled insulin at $4^{\circ} \mathrm{C}$ for $10 \mathrm{~h}$ in a medium of $150 \mathrm{mM} \mathrm{NaCl}$ and $50 \mathrm{mM}$ Hepes at $\mathrm{pH}$ 7.4 containing $0.1 \%$ BSA. Separation of receptor-bound and free insulin was performed by the polyethylene glycol method using bovine gamma globulin as carrier protein (31).

Identification of hepatic phosphotyrosine containing proteins in vivo. A recently developed procedure was employed to measure in vivo phosphorylation involving the analytical isolation of phosphotyrosine containing proteins which appear in response to hormonal stimulation of intact tissues (Rothenberg, P., manuscript in preparation). Mice were anesthetized with sodium amobarbital $(20 \mathrm{mg} / \mathrm{kg}$ body wt, i.p.). The abdominal wall was incised to expose the viscera. Normal saline with or without $10^{-6} \mathrm{M}$ insulin (Humulin R, Eli Lilly Co., Indianapolis, IN) was infused into the portal vein for $20 \mathrm{~s}$ at a rate of $0.2 \mathrm{ml} / \mathrm{min}$. The entire liver was then excised and homogenized in $1 \% \mathrm{SDS}, 50 \mathrm{mM}$ dithiothreitol, $100 \mathrm{mM}$ Hepes, $2 \mathrm{mM}$ EDTA, pH 7.5, at $100^{\circ} \mathrm{C}$ for 5 $\mathrm{min}$. The denatured proteins were precipitated with TCA (10\% wt/vol). The TCA was removed using three washings with $1: 1$ ( $\mathrm{vol} / \mathrm{vol})$ ether:ethanol. The proteins were resuspended in $50 \mathrm{mM}$ Tris buffer, pH 7.5, and immunoprecipitated with rabbit polyclonal anti-phosphotyrosine antibodies. Immunoprecipitated phosphotyrosyl proteins were resolved on $6 \%$ SDS polyacrylamide gels, transferred to nitrocellulose, and detected with anti-phosphotyrosine antibodies and $\left[{ }^{125} \mathrm{I}\right]-$ protein $A$. The nitrocellulose membranes were then subjected to autoradiography.

Electron microscopy. After cervical dislocation, the right lobe of the liver was rapidly excised, minced in cold $2.5 \%$ glutaraldehyde, $0.1 \mathrm{M}$ phosphate buffer, pH 7.4 and fixed in fresh fixative at $4^{\circ} \mathrm{C}$ overnight. Tissue was rinsed in the same buffer, fixed with osmium, dehydrated in graded alcohols, and embedded in Araldite. Ultrathin sections were picked up on copper grids and stained with uranyl acetate and lead citrate. Areas adjacent to portal triads were viewed using a Phillips 301 electron microscope.

Analytic methods. Blood glucose levels were determined using ACCU-CHEC II (Boehringer Mannheim Diagnostics Division, Indianapolis, IN). Plasma immunoreactive insulin concentration was determined by radioimmunoassay using the polyethylene glycol method (31). Serum concentrations of vanadate were determined by flameless atomic absorption spectroscopy (32). The lower limit of detection was $7 \mathrm{nM}$ concentration. Protein concentrations were determined by the method of Bradford (33) using IgG immunoglobulin as a standard.

Data are presented as mean \pm SEM. The unpaired Student's $t$ test (two-tailed) was used to compare two groups, and analysis of variance was used to compare more than two groups using Bonferroni correction where applicable. 
Table I. Characteristics of Mice

\begin{tabular}{lcccc}
\hline Groups & No. & Body weight & Blood glucose & Insulin \\
\hline & & $g$ & $m g / d l$ & $\mu U / m l$ \\
$\mathrm{ob} /+$ & 6 & $32.4 \pm 0.1$ & $64 \pm 2$ & $44 \pm 7$ \\
$\mathrm{ob} / \mathrm{ob}$ & 6 & $45.0 \pm 0.1^{*}$ & $406 \pm 2^{*}$ & $170 \pm 30^{*}$ \\
$\mathrm{db} /+$ & 6 & $32.2 \pm 0.2$ & $70 \pm 2$ & $27.2 \pm 2$ \\
$\mathrm{db} / \mathrm{db}$ & 6 & $36.8 \pm 0.4^{*}$ & $319 \pm 2^{*}$ & $410 \pm 24^{*}$ \\
& & & &
\end{tabular}

The data are represented as the mean \pm SEM.

* $P<0.001$ for ob/ob vs. ob/+ and db/db vs. $\mathrm{db} /+$.

\section{Results}

Data concerning blood glucose, body weight, and plasma insulin levels in ob/ob and db/db mice and their matched controls are presented in Table I. Blood glucose and serum insulin levels, as well as the body weights, were markedly increased in the both diabetic models compared to the control mice.

Effect of vanadate treatment on ob/ob mice. After $47 \mathrm{~d}$ of treatment with vanadate, the blood glucose level of the treated ob/ob mice was $143 \pm 2 \mathrm{mg} / \mathrm{dl}$ compared to $276 \pm 3 \mathrm{mg} / \mathrm{dl}$ in the control untreated ob/ob mice $(P<0.001$, Table II and Fig. 1 $A)$. The vanadate treatment also lowered the blood glucose level of lean ob/+ mice from $170 \pm 4 \mathrm{mg} / \mathrm{dl}$ to $114 \pm 1 \mathrm{mg} / \mathrm{dl}(P$ $<0.001$ ). In both the ob/ob and the ob/+ groups, there was no difference in body weight in the vanadate-treated mice as compared with their appropriate saline-treated controls (Table II). Circulating level of vanadate were $5.2 \pm 0.9 \mu \mathrm{M}$ and $2.7 \pm 0.5$ $\mu \mathrm{M}$ in the ob/+ mice after $3 \mathrm{wk}$ of treatment. These levels are similar to vanadate levels previously reported by us and others $(9,10)$. Untreated mice have no detectable $(<7 \mathrm{nM})$ serum vanadate (32). The effect of vanadate was reversible and $20 \mathrm{~d}$ after withdrawal of the vanadate, the blood glucose returned to the initial hyperglycemic level (Fig. $1 B$ ). To determine the possible mechanism of this vanadate effect, we evaluated serum insulin level, insulin receptor function, and some postreceptor sites of hormone action.

Vanadate treatment increased plasma insulin levels in the ob/ob mice from $272 \pm 25$ to $398 \pm 40 \mu \mathrm{U} / \mathrm{ml}(P<0.005)$, but had no significant effect in the ob/+ group $(57 \pm 10$ to $68 \pm 15)$ $(P>0.05)$. In view of the fact that ob/ob mice fail to respond to even massive doses of insulin (19) and the fact that vanadate produced a similar, normoglycemic effect in $\mathrm{db} / \mathrm{db}$ with a low-

Table II. Effect of Vanadate Treatment on ob/ob Mice

\begin{tabular}{llcccc}
\hline Groups & Treatment & Body weight & Blood glucose & Insulin & Binding \\
\hline & & $g$ & $m g / d l$ & $\mu U / m l$ & $\% / 10 ~ m g$ \\
ob/t & Control & $35.3 \pm 0.1$ & $170 \pm 4$ & $57 \pm 10$ & $17.3 \pm 3.8$ \\
ob/+ & Vanadate & $34.9 \pm 0.2$ & $114 \pm 1^{*}$ & $68 \pm 15$ & $10.3 \pm 1.9$ \\
ob/ob & Control & $40.0 \pm 0.1$ & $276 \pm 3$ & $272 \pm 25$ & $8.7 \pm 1.8$ \\
ob/ob & Vanadate & $40.0 \pm 0.2$ & $143 \pm 2^{*}$ & $398 \pm 40^{*}$ & $7.3 \pm 1.3$
\end{tabular}

The vanadate treatment was for $47 \mathrm{~d}$; controls received saline only in their drinking water. Ob/ob mice differ from ob/+ in weight and blood glucose $(P<0.001)$. The data are represented as the mean \pm SEM. Sample size is five per group. ${ }^{*} P<0.005$ compared with nontreated mice.
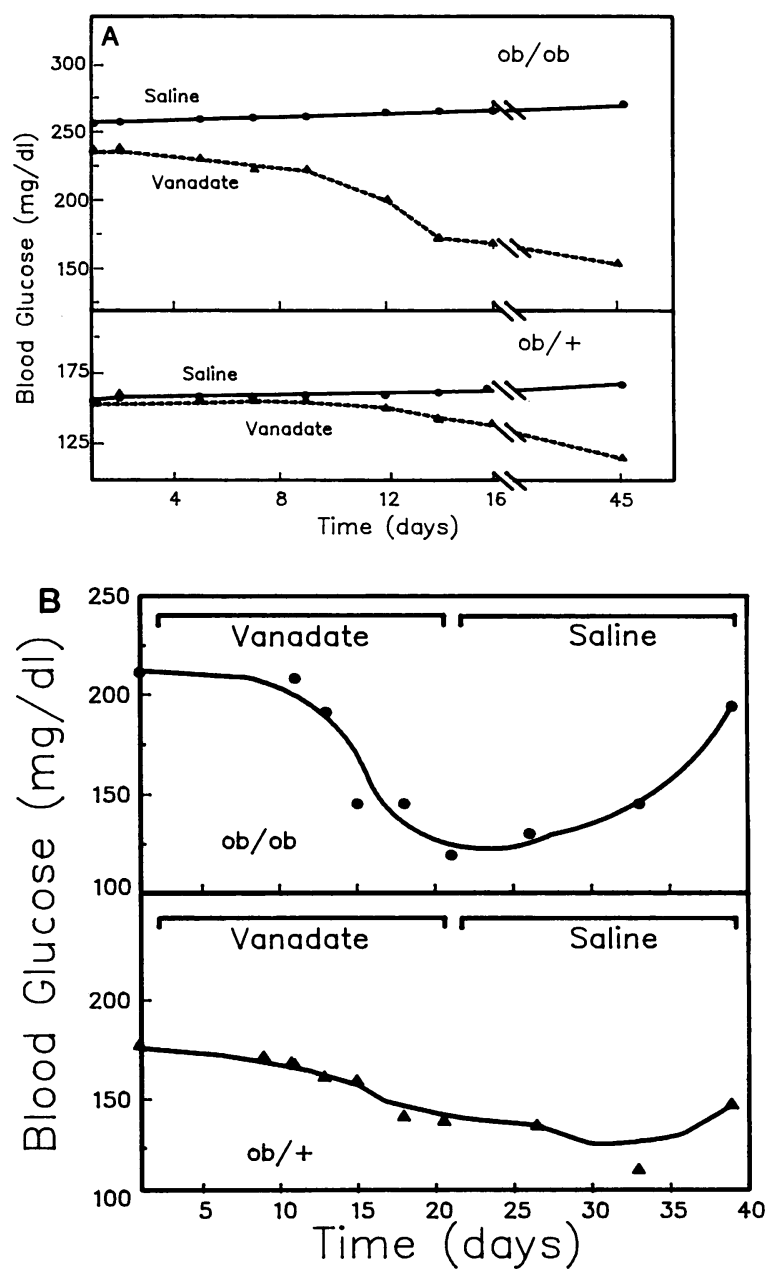

Figure 1. $(A)$ Effect of oral administration of vanadate on ob/ob mice on blood glucose level. Ob/ob mice (upper panel) and their matched controls ob/+ (lower panel) were treated with vanadate $\left(\mathrm{NaVO}_{3}, 0.25\right.$ $\mathrm{mg} / \mathrm{ml}$, and $80 \mathrm{mmol} /$ liter $\mathrm{NaCl}$ ) in the drinking water (solid lines) or with $80 \mathrm{mmol} /$ liter $\mathrm{NaCl}$ alone (dashed lines). Each point is the mean of five animals. SEM was $2-3 \mathrm{mg} / \mathrm{dl}$. (B) The effect of vanadate is reversible. The vanadate drinking water was changed to control after $20 \mathrm{~d}$. The ob/ob mice are shown in the upper panel and the ob/t+ mice in the lower panel. Each point is the mean of five animals. SEM was 2-3 mg/dl.

ering of insulin levels (see below) it seems unlikely that this modest increase in insulin is responsible for the normalization of glucose. Insulin binding to WGA-purified insulin receptors was reduced in the untreated ob/ob mice $(8.7 \pm 1.8 \% / 10 \mu \mathrm{g}$ protein compared with $17.3 \pm 3.8 \% / 10 \mu \mathrm{g}$ protein in untreated controls) (Table II). After $47 \mathrm{~d}$ of vanadate treatment there was still a decrease in the insulin binding in the ob/ob mice $(8.7 \pm 1.8 \%$ / $10 \mu \mathrm{g})$, whereas the vanadate treatment downregulated the level of insulin binding in the ob/ + mice to $10.3 \pm 1.9 \% / 10 \mu \mathrm{g}$ protein, although these changes did not reach statistical significance (Table II).

At the ultrastructural level, the livers of obese mice were heavily laden with glycogen and lipid droplets (Fig. 2) with considerable variability from cell to cell. There was an increasing gradient in the number of lipid droplets from the portal triad to the central vein. For this reason we compared hepato- 

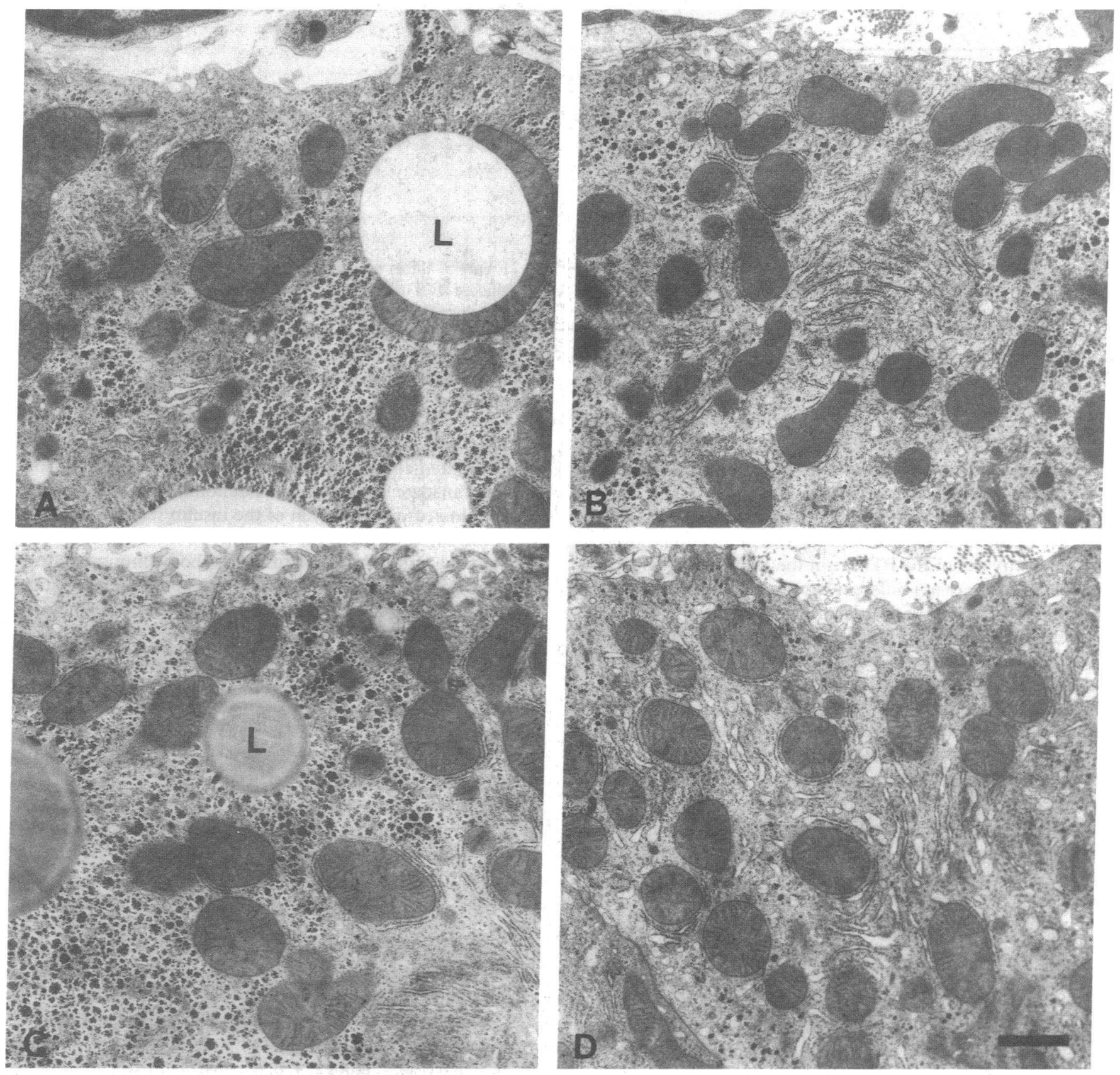

Figure 2. Micrograph of liver from ob/ob control $(A)$, lean ob/+ control $(B)$, ob/ob treated with vanadate $(49 \mathrm{~d})(C)$, and lean treated with vanadate $(D)$. Areas adjacent to portal triads are shown with sinusoid face at top of each micrograph. Hepatocytes from ob/ob were more heavily laden with lipid droplets $(L)$ and glycogen than those from lean litter mates. There was much variation within adjacent cells. Nonetheless, no major toxic effects of vanadate were evident in either ob/ob nor lean ob/+ treated. Bar, $1 \mu \mathrm{m}$.

cytes from the portal triad from all groups (Fig. 2). With both the ob/ob or lean ob/+, there was no apparent difference between vanadate-treated and control mice.

Effect of vanadate treatment on $\mathrm{db} / \mathrm{db}$ mice. Treatment of $\mathrm{db} / \mathrm{db}$ mice with vanadate lowered the blood glucose level from $228 \pm 6$ to $141 \pm 1 \mathrm{mg} / \mathrm{dl}(P<0.001)$. This effect was maximal after $55 \mathrm{~d}$ of treatment, with half the effect observed after $23 \mathrm{~d}$ (Fig. 3). This was associated with a $40 \%$ decrease in insulin level (Table III). The vanadate treatment also lowered the blood glucose level of the db/+ mice from $126 \pm 2$ to $81 \pm 1 \mathrm{mg} / \mathrm{dl}$ after
$55 \mathrm{~d}$. There was no difference in body weight gain during treatment with vanadate or with saline for either the $\mathrm{db} / \mathrm{db}$ or the $\mathrm{db} /+$ groups (Table III). The effect of vanadate was reversible, and $25 \mathrm{~d}$ after withdrawal of the vanadate the blood glucose returned to the initial hyperglycemic level (Fig. 3).

Effect of diabetes and vanadate on PTPase activity. PTPase activity present in cytosolic extracts of liver from the 8-wk-old ob/ob mice was $55 \%$ that of the ob/ $+(0.18 \pm 0.02 \mathrm{U} / \mathrm{mg}$ and $0.33 \pm 0.03 \mathrm{U} / \mathrm{mg}, P<0.01)$ when assessed in vitro using the phosphorylated $1142-1153$ peptide as substrate (Fig. $4 A$ ). 


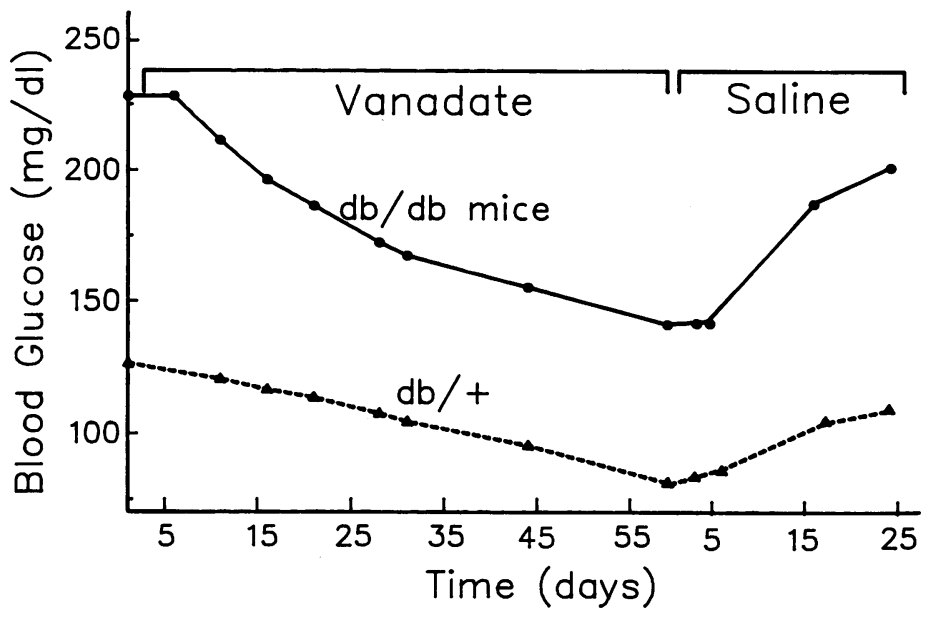

Figure 3. Effect of oral administration of vanadate on blood glucose level in $\mathrm{db} / \mathrm{db}$ mice. $\mathrm{Db} / \mathrm{db}$ mice (solid line) and their match controls $\mathrm{db} /+$ (dashed line) were treated with vanadate as described in Fig. $1.60 \mathrm{~d}$ after treating the mice, the vanadate had been changed into the control solution. Each point is the mean of five or six mice. SEM was $2-3 \mathrm{mg} / \mathrm{dl}$.
PTPase activity associated with the particulate fractions was similarly decreased in the ob/ob mice versus the ob/+ controls $(1.4 \pm 0.2 \mathrm{U} / \mathrm{mg}$ and $2.1 \pm 0.3 \mathrm{U} / \mathrm{mg}, P<0.02$ ) (Fig. $4 B$ ). The glycoprotein fraction of the membrane had five- to eightfold higher specific activity than the particulate fraction, however, specific activities of the PTPase in the WGA-purified particulate fractions were not different between ob/ob and ob/+ mice (16.1 $\pm 1.3 \mathrm{U} / \mathrm{mg}$ vs. $16.8 \pm 1 \mathrm{U} / \mathrm{mg}$, Fig. $3 \mathrm{~B}$ ).

In the 8-wk-old $\mathrm{db} / \mathrm{db}$ mice, the cytosolic PTPase activity was also decreased by $\sim 50 \%(0.25 \pm 0.03 \mathrm{U} / \mathrm{mg}$ vs. $0.47 \pm 07$ $\mathrm{U} / \mathrm{mg}, P<0.02$ ) (Fig. $5 A$ ). No significant difference was found in the PTPase activity associated with the particulate fraction (Fig. $5 \mathrm{~B}$ ), and thus activity in the glycoprotein fractionenriched fraction was not determined.

After 9 wk of treatment, vanadate did not significantly alter particulate PTPase activity in ob/ob mice (Fig. 6) or $\mathrm{db} / \mathrm{db}$ mice (data not shown) compared with their age-matched untreated controls. The specific activity of the PTPase activity in the particulate fraction of the ob/ob mice was $55 \%$ of ob/t+ $(2.9 \pm 0.4 \mathrm{U} / \mathrm{mg}$ vs. $5.3 \pm 0.9 \mathrm{U} / \mathrm{mg}, P<0.02)$ (Fig. 6). Vanadate treatment did result in a decrease in PTPase activity in the $\mathrm{ob} /+$ mice $(3.9 \pm 0.5 \mathrm{U} / \mathrm{mg}$ in the treated vs. $5.3 \pm 0.5$ in the control animals); however, the change was not statistically significant (Fig. 6). No significant differences in cytosolic PTPase activity was observed in this age group (data not shown).

Table III. Effect of Vanadate Treatment on $\mathrm{db} / \mathrm{db}$ Mice

\begin{tabular}{llcccc}
\hline Groups & Treatment & No. & $\begin{array}{c}\text { Body weight } \\
\text { change }\end{array}$ & $\begin{array}{c}\text { Blood } \\
\text { glucose }\end{array}$ & Insulin \\
\hline & & & \multicolumn{1}{c}{$g / d$} & $m g / d l$ & $m U / m l$ \\
& & & $0.05 \pm 0.003$ & $106 \pm 1$ & $42 \pm 3$ \\
$\mathrm{db} /+$ & Control & 5 & $0.06 \pm 0.02$ & $104 \pm 1$ & $48 \pm 5$ \\
$\mathrm{db} /+$ & Vanadate & 6 & $0.06 \pm 0.002$ & $191 \pm 2$ & $339 \pm 52$ \\
$\mathrm{db} / \mathrm{db}$ & Control & 5 & $0.06 \pm 0.003$ & $167 \pm 1^{\ddagger}$ & $198 \pm 10^{\ddagger}$ \\
$\mathrm{db} / \mathrm{db}$ & Vanadate & 6 & $0.06 \pm 0.003$
\end{tabular}

Mice were treated with vanadate for $31 \mathrm{~d}$, then received saline only in their drinking water for $3 \mathrm{wk}$. Db/db mice different from $\mathrm{db} /+$ in body weight, insulin, and blood glucose level $(P<0.001)$. The data are represented as the mean \pm SEM. ${ }^{*} P<0.025$ compared with $\mathrm{db} / \mathrm{db}$ with control treatment.

${ }^{\ddagger} P<0.001$ compared with $\mathrm{db} / \mathrm{db}$ with control treatment.
Effect of vanadate treatment on tyrosyl phosphorylation in vivo of 95 and $185 \mathrm{kD}$. To determine whether the administration of vanadate produced its insulinomimetic metabolic effects by increasing activation of the insulin receptor, we analyzed the phosphotyrosyl proteins which occur in intact mouse liver using an anti-phosphotyrosine antibody immunoblotting method. After insulin infusion into the portal vein of intact, live mice, phosphotyrosyl proteins were isolated and analyzed as described in Experimental Procedures.

Without acute insulin infusion, a major, constitutively phosphotyrosine-containing protein of $M_{\mathrm{r}} 120 \mathrm{kD}$ was present in all animals (Fig. 7). The identity of this band is unknown, although it has been previously observed (34), and its phosphotyrosine content was not influenced by vanadate or insulin treatment. There was also a low level of $\beta$-subunit phosphotyrosine attributable to receptor activation by endogenous, circulating insulin (Fig. 7, at $M_{\mathrm{r}} 95 \mathrm{kD}$ compare lane 5 with 1 and lane 7 with 3), however, vanadate treatment did not increase this basal level of insulin receptor autophosphorylation. This observation was replicated in three experiments in both ob/+ and ob/ob $(-12.1 \pm 13.4 \%$; mean percent difference of control vs. vanadate treated $\pm \mathrm{SD}, n=6$ ). Moreover, no new phosphotyrosyl proteins were detected in the vanadate-treated mice compared with control mice.

After intraportal insulin infusion a 95-kD band, consistent with the insulin receptor $\beta$-subunit, became prominently phosphorylated (Fig. 7, lanes $2,4,6,8+$ ins). The extent of receptor autophosphorylation is similar in all animals, although there was a modest decrease $(-38 \pm 10 \%$; mean $\pm \mathrm{SD}, n=3)$ in the ob/ob diabetic mice compared with ob/+ controls. Vanadate treatment did not significantly alter receptor autophosphorylation in either the ob/+ mice ( $17 \%$ mean increase, $n=2)$ or in the ob/ob diabetic animals ( $26 \%$ decrease, $n=1)$.

In addition to the $95-\mathrm{kD}$ receptor band, insulin infusion stimulated the appearance of a distinct phosphotyrosyl protein migrating between 170 and $185 \mathrm{kD}$. This has been previously identified as pp185, a putative, endogenous substrate of the insulin receptor kinase (34). In the ob/+ mouse liver, pp185 appeared as a closely spaced protein doublet, whereas in the ob/ob mice the upper band of pp 185 was of much lower intensity as compared to ob/+ controls (Fig. 7, compare lane 4 with 2 , and lane 8 with 6 ). As was true for the insulin receptor, vanadate treatment did not increase the basal level of pp185 

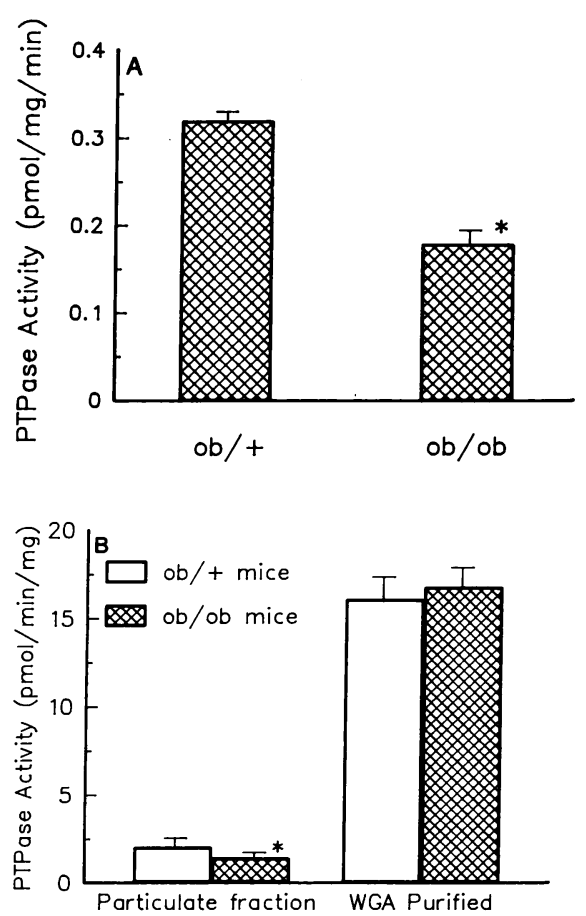

Figure 4. PTPase activity in cytosolic fractions $(a)$ and particulate and WGA-purified fractions $(b)$ from livers of ob/ob and ob/+ mice. Liver fraction derived from ob/ob and ob/+ mice were fractionated using isotonic sucrose differential centrifugation. The particulate fraction was then further fractionated on WGA columns. The 11421153 peptide was phosphorylated at $4^{\circ} \mathrm{C}$ in the presence of $100 \mathrm{nM}$ insulin using WGA-purified insulin receptor as described in the methods. The ${ }^{32} \mathrm{P}$-labeled peptide was separated from the ${ }^{32} \mathrm{P}-\mathrm{ATP}$ by chromatography on AG 1-X2 acetate column and by SEP-PAK cartridge and lyophilized. Aliquots from each fraction were assayed for PTPase activity towards the phosphorylated peptides $(0.14 \mu \mathrm{M})$ in the presence of $2 \mathrm{mM}$ EDTA and $1 \mathrm{mM}$ DTT for $5 \mathrm{~min}$ at $30^{\circ} \mathrm{C}$. The reaction was stopped by precipitation with $10 \%$ TCA, and ${ }^{32} P_{i}$ release was measured by organic extraction of $P_{i}(27)$. The results represent the mean \pm SEM of six mice in each group assayed in duplicate. (a) Cytosolic PTPase activity in ob/ob mice and their controls. * $<0.01$. (b) Particulate and WGA-purified PTPase activity in ob/ob mice and their controls. ${ }^{*}<0.02$.

tyrosine phosphorylation in either ob/+ or ob/ob mice (Fig. 7, compare lane 5 with 1 , and lane 7 with $3 ; 7.3 \pm 12.5 \%$; mean difference of control vs. vanadate treated $\pm \mathrm{SD}, n=6$ ). The effect of vanadate treatment on the extent of stimulated pp 185 tyrosine phosphorylation after acute insulin infusion was variable with a twofold augmentation in ob/+ mice in the experiment shown in Fig. 7 (lane 6 vs. lane 2), but no such augmentation was not evident in ob/ob mice (compare lane 8 with lane 4 ), nor was it as evident in a replicate experiment with ob/+ controls.

\section{Discussion}

Tyrosine phosphorylation is an important regulatory process $(1,2,35-37)$. The level of phosphotyrosine in the cell is a balance between the actions of protein tyrosine kinases and protein tyrosine phosphatases. In nontransformed tissues, the major tyrosyl kinases are the receptors for certain peptide hor-
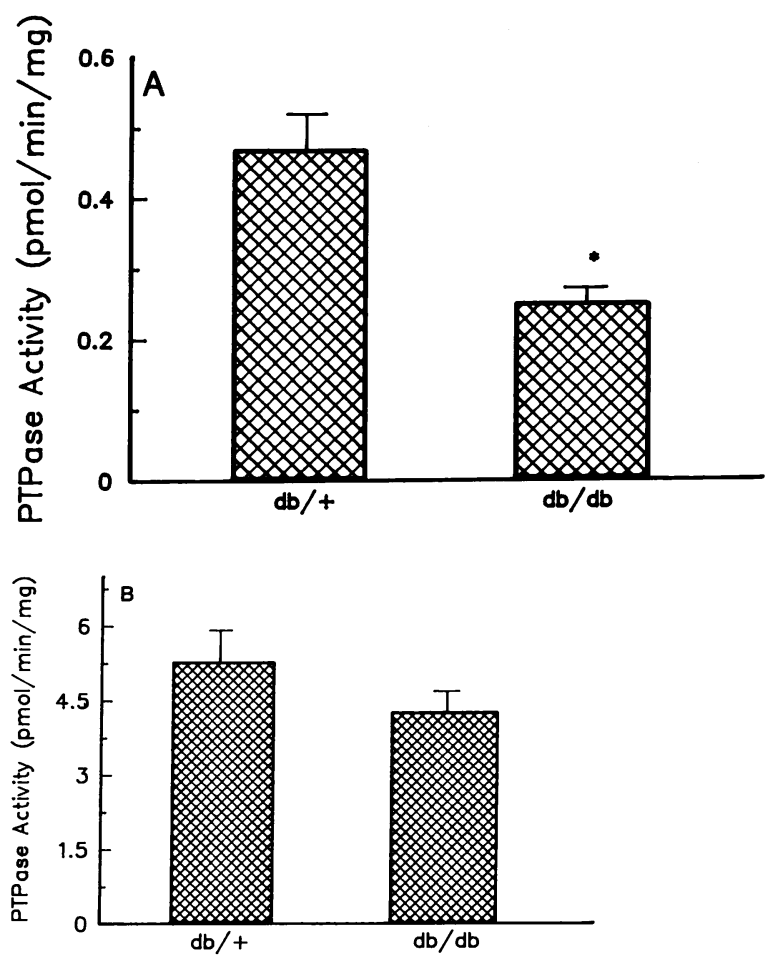

Figure 5. PTPase activity in cytosolic fractions (a) and particulate fractions $(b)$ from $\mathrm{db} / \mathrm{db}$ mice livers. PTPase activity was assayed in cytosolic and in particulate fractions. Liver fractionation and PTPase assay methods were as described in Fig. $3^{*}<0.02$.

mones and growth factors, such as insulin, IGF-I, epidermal growth factor and platelet-derived growth factor. PTPase activity has been detected in a variety of tissues and cell lines. These enzymes have molecular weights between $23 \mathrm{kD}$ (in rat brain) and $200 \mathrm{kD}$ (CD 45 in lymphocytes) and are distinct from phosphoserine phosphatases based on their primary sequence, substrate specificity, activity in the presence of EDTA and sodium fluoride, selective inhibition by micromolar concentration of zinc and vanadate (reviewed in references 38,39 ). The exact number of enzymes in the family, their physiologic roles, and their regulation are uncertain.

We have studied the alterations in hepatic PTPase and tyrosine phosphorylation as a possible explanation for blunted response to insulin in two rodent models of obesity-associated diabetes, the ob/ob and $\mathrm{db} / \mathrm{db}$ mice $(16,40)$. The decrease in

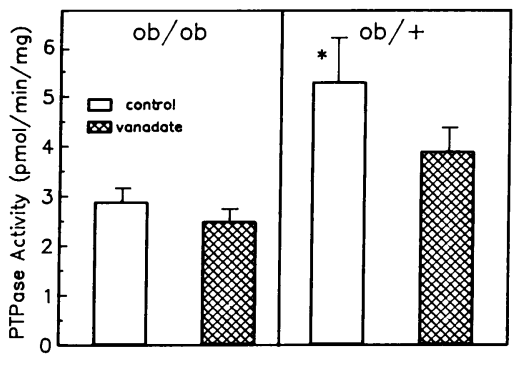

Figure 6. Effects of vanadate treatment on PTPase activity in particulate fractions from ob/ob mice liver. (Left) ob/ob mice; (right) ob/ $1^{+}$mice. $47 \mathrm{~d}$ after oral administration of vanadate (hatched bars) or solution (open bars). Particulate PTPase activity from the ob/ob mice livers was assayed as described in Fig. 3. The results represent mean \pm SEM of five mice in each group assayed in duplicate. ${ }^{*} P<0.02$. 


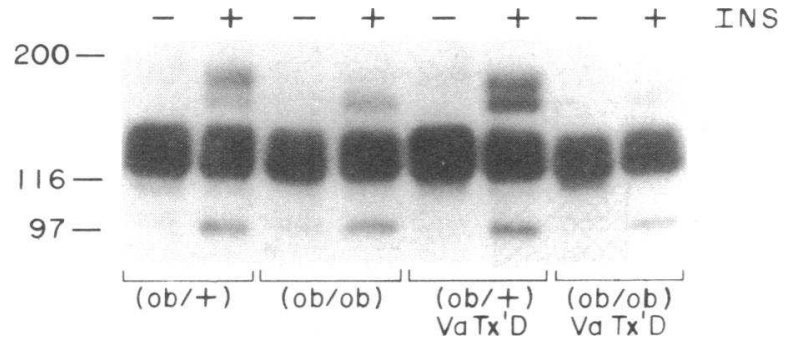

Figure 7. Insulin-stimulated tyrosine phosphorylation in ob/ob mice. $\mathrm{Ob} / \mathrm{ob}$ and control mice were treated for $9 \mathrm{wk}$ with vanadate or control solutions. Phosphotyrosyl proteins from the liver were isolated as described in Methods. Briefly, mice were anesthetized, the abdominal wall was incised to expose the viscera. Normal saline (lanes 1,3 , 5,7 ) or $10^{-6} \mathrm{M}$ insulin (lanes $2,4,6,8$ ) was infused for $20 \mathrm{~s}$, after when the liver excised and homogenized in $1 \%$ SDS, $100 \mathrm{mM}$ Hepes, $\mathrm{pH} 7.5,50 \mathrm{mM}$ DTT at $100^{\circ} \mathrm{C}$ for $5 \mathrm{~min}$. The denatured proteins were precipitated with TCA and immunoprecipitated with polyclona antiphosphotyrosine antibodies. The immunoprecipitated phosphotyrosyl proteins were resolved on 6\% SDS-polyacrylamide gels, transferred to nitrocellulose, and detected with antiphosphotyrosine antibodies and $\left[{ }^{125} \mathrm{I}\right]$-protein $\mathrm{A}$ and subject to autoradiography. The experiment was performed twice with similar results.

insulin action in these models is associated with decreased receptor number $(16,21,25)$, but the activity of the receptor tyrosine kinase, when corrected per insulin binding, appears to be normal $(23,24$; Yamada, K., et al., personal communication). Thus, the major defects in these models seem to be a decrease in the number of insulin receptors and alterations at the postreceptor level. In both models there were significant decreases in the cytosolic PTPase activity, whereas the particulate PTPase activity decreased significantly only in ob/ob mice. Although a synthetic substrate was used in these studies for improved quantitation, the tissue preparations were also active in dephosphorylation of the autophosphorylated insulin receptor under the same assay conditions (26, Meyerovitch, J., J. M. Backer, M. F. White, and C. R. Kahn, submitted for publication), suggesting that the PTPases being assessed are those which are potentially involved in the insulin receptor dephosphorylation.

The exact relationship between the cytosolic, particulate, and glycoprotein-enriched PTPase activities is uncertain; however, some differences have been noted between the enzyme activities in these two fractions. Previous work (41) has suggested that a membrane-bound PTPase in the kidney can be distinguished from its cytosolic counterpart based on differential elution from DEAE-Sepharose, thermal lability, and sensitivity to dodecyl sulfate. On the other hand, Tonks et al. (42) reported that little difference could be detected between the cytosolic and particulate forms of the enzymes purified from human placenta. In previous studies, we reported that the two enzymes are different both in response to acute stimulation with insulin (Meyerovitch et al., submitted for publication) and in chronic insulin-deficient states (26). Recent studies employing cDNA cloning have suggested that the PTPases are a family of related molecules, some being cytosolic and others being transmembrane glycoproteins $(38,39)$.

The mechanism of regulation of PTPases is largely unknown. We have demonstrated an effect of insulin on both membrane and cytoplasmic PTPases in rat hepatoma cells
(Meyerovitch et al., submitted for publication) suggesting that insulin may affect both the phosphorylation state and the activity of the PTPase in a manner similar to changes observed for some other insulin-regulated enzymes (reviewed in 34). Hormonally-stimulated translocation of the PTPases might provide another regulatory mechanism, in a manner analogous to the translocation of the glucose transporter and protein kinase C (43-46), although our own study suggests that this is not the case (Meyerovitch et al., submitted for publication). Change in the level of PTPase inhibitor (47) or activator similar to the insulin-stimulated redistribution of the $\mathrm{Mg}^{2+}$ ATP-dependent multifunctional protein phosphatase activator which has been demonstrated in human platelets (48) could provide additional possible mechanisms. In addition, a primary defect in the PTPase protein structure or level of expression are other possibilities. In the case of the ob/ob and db/db mice, the decrease in PTPase activity may reflect a decreased level of PTPase activity in response to the decrease level of protein tyrosine phosphorylation, or an inability of insulin receptor to activate the membrane PTPase activity (Meyerovitch et al., submitted for publication).

The pp 185 has been described as the major substrate for the insulin receptor (reviewed in 28,34 ), and its decreased level of tyrosine phosphorylation in ob/ob mice is striking and may well be a major factor in the insulin resistance. It is also apparent in these studies that there is a second endogenous substrate band at $\sim 160 \mathrm{kD}$ which is not altered in phosphorylation in ob/ob mice, and because the insulin receptor kinase activity toward an exogenous substrate was also found to be unchanged when assayed in vitro (data not shown), a specific defect in pp1 185 is suggested. Currently we are studying the nature of this defect which may reflect either a decreased level of the protein, mutation in the protein, or subtle changes in the ability of the insulin receptor to phosphorylate $\mathrm{pp} 185$. Alterations of the insulin receptor tyrosine kinase in vivo due to changes associated with the diabetic state, such as changes in the membrane composition or changes in serine phosphorylation, are other possible mechanisms of the altered activity of the insulin receptor in vivo.

In the present study we have demonstrated that vanadate administration significantly lowered blood glucose levels in two mouse models of NIDDM. The effect of the vanadate treatment was slow in onset with half the effect being observed after 2 wk of treatment. This is in contrast to the dramatic effect which occurs after only 2-4 d in STZ-treated diabetic rats (9). Although vanadate has been shown to reduce appetite in normal rats through an effect in the central nervous system (49), the hypoglycemic effect in the NIDDM rodent models occurs without an effect on body weight, suggesting that the mechanism of action of vanadate is not mediated through decreased food intake.

The exact site of action of vanadate remains uncertain (reviewed in reference 7). Some groups have found that vanadate directly stimulates $\beta$-subunit tyrosine autophosphorylation and in vitro phosphotransferase activity of purified insulin receptors (13), but this has not been observed in all studies (14). One previous study suggests that the effect of vanadate is not mediated through changes in the phosphorylation of the insulin receptor $(50)$. In this study we have found that vanadate produced a variable enhancement of insulin-stimulated tyrosine phosphorylation of pp185 in the ob/+ mice but had no 
effect in ob/ob mice. Our study differs from the former study in that the administration of vanadate was chronic rather than acute. In addition, we have used a technique which enables a rapid isolation of phosphoproteins and thereby increases the sensitivity of the assay. The lack of effect of vanadate administration on the level of tyrosine phosphorylation of the $\beta$-subunit of the insulin receptor and its putative substrate in ob/ob mice suggests that its primary action may be at a step distal to these tyrosine phosphorylations. However, we cannot rule out changes in tyrosine phosphorylation of substrates which could be detected only under other conditions (51).

Vanadate can affect directly the activity of several enzymes in vitro (7), and vanadate administration has been shown to restore the level of fructose 2,6-biphosphate activity in the STZ diabetic rats (10) and normalize the glucose uptake and glycogen synthetase in diabetic muscle (52). Normalization of the activity of these enzymes which are increased in both mice models of NIDDM (17-20) is a possible mechanism of action of vanadate.

This study demonstrates that vanadate is an effective oral hypoglycemic agent and produces a normoglycemic state in two rodent models of NIDDM. This effect appears to occur as a result of action at a step distal to the tyrosine phosphorylations of the insulin receptor and the pp185. No hepatotoxicity was detected in the present study at the ultrastructure level after 7 wk of vanadate treatment. Likewise, no changes in liver or kidney function have been reported by us and others in STZ diabetic rats (9). Although more studies are necessary to evaluate the long-term toxicity, and the appropriate dose of vanadate, these data suggest that vanadate administration may offer a new therapeutic approach to diabetes and insulin resistance states either alone or in combination with conventional therapy.

\section{Acknowledgments}

The authors would like to thank Dr. J. Warram for helping in statistical analysis, M. Petruzzelli for technical assistance with animal care, Sarah Curtis and Terri-Lyn Bellman for secretarial assistance and Christopher J. Cahill for technical assistance with electron microscopy.

This work was supported in part by Juvenile Diabetes Foundation grant 188182, National Institutes of Health (NIH) grant DK 31036 (CRK), and NIH BRSG-RR05673, the Joslin Diabetes and Endocrinology Research Center grant (DK 36836) and the Pfizer Biomedical Research Award.

\section{References}

1. Kasuga, M., F. A. Karlsson, and C. R. Kahn. 1982. Insulin stimulates the phosphorylation of the 95,000 dalton subunit of its own receptor. Science (Wash. DC). 215:185-187.

2. White, M. F., and C. R. Kahn. 1986. The insulin receptor and tyrosine phosphorylation. In The Enzymes. P. D. Boyer and E. G. Krebs, editors. Academic Press, Inc., New York. 248-285.

3. Rosen, O. M., R. H. Herrera, Y. Olowe, L. M. Petruzzelli, and M. H. Cobb. Phosphorylation activates the insulin receptor tyrosine protein kinase. Proc. Natl. Acad. Sci. USA. 80:3237-3240.

4. Yu, K. T., and M. P. Czech. 1984. Tyrosine phosphorylation of the insulin receptor $\beta$-subunit activates the receptor-associated tyrosine kinase activity. $J$. Biol. Chem. 259:5277-5286.

5. Ellis, L., E. Clauser, D. O. Morgan, M. Edery, R. A. Roth, and W. J. Rutter. 1986. Replacement of insulin receptor tyrosine residues 1162 and 1163 compromises insulin stimulated kinase activity and uptake of 2-deoxyglucose. Cell. 45:721-732.

6. Chow, C. K., T. J. Dull, D. S. Russell, R. Gherzi, D. Lebwol, A. Ullich, and O. M. Rosen. 1987. Human insulin receptor mutated at the ATP binding site lack protein tyrosine kinase activity and fail to mediate postreceptor effect of insulin. J. Biol. Chem. 262:1842-1847.

7. Shechter, Y., J. Meyerovitch, and S. Amir. 1988. The use of post-binding agents in studying insulin action and its relation to experimental diabetes. Biochem. Pharmacol. 37:1891-1896.

8. Heyliger, C. E., G. A. Tahiliani, and T. H. McNeill. 1985. Effect of vanadate on elevated blood glucose and depressed cardiac performance of diabetic rats. Science (Wash. DC). 227:1474-1476.

9. Meyerovitch, J., Z. Farfel, J. Sack, and Y. Shechter. 1987. Oral administration of vanadate normalizes blood glucose levels in streptozotocin-treated rats. $J$. Biol. Chem. 262:6658-6662.

10. Gil, J., M. Miralpeix, J. Carreras and R. Bartons. 1988. Insulin-like effects of vanadate on glucokinase activity and fructose 2,6-bisphosphate levels in the liver of diabetic rats. J. Biol. Chem. 263:1868-1876.

11. Swarup, G., K. V. Speeg, Jr., S. Cohen, and D. L. Garbers. 1982. Phosphotyrosyl-protein phosphatase of TCRC-2 cells. J. Biol. Chem. 257:7298-7301.

12. Swarup, G., S. Cohen, and D. L. Garbers. 1982. Inhibition of membrane phosphotyrosyl protein phosphatase activity by vanadate. Biochem. Biophys. Res. Commun. 107:1104-1109.

13. Tamura, S., T. A. Brown, J. H. Whipple, Y. F. Yamaguchi, R. E. Dubler, M. Chelany, and J. Larner. 1984. A novel mechanism for the insulin-like effect of vanadate on glycogen synthase in rat adipocytes. J. Biol. Chem. 259:6650-6658.

14. Machicao, F., T. Urumow, and O. H. Wieland. 1983. Evidence for phosphorylation of actin by the insulin receptor associated protein kinase from human placenta. FEBS (Fed. Eur. Biochem. Soc.) Lett. 163:76-80.

15. Green, A. 1986. The insulin-like effect of sodium vanadate on adipocyte glucose transport is mediated at a post insulin receptor level. Biochem. J. 238:663-669.

16. Mordes, J. P., and A. A. Rossini. 1985. Animal models of diabetes mellitus. In Joslin's Diabetes Mellitus. A. Marble, L. P. Krall, R. F. Bradley, H. R Christlieb, and J. S. Soeldner, editors. Lea and Febiger, Philadelphia. 110-137.

17. Seidman, I., A. A. Horland, and G. W. Teebor. 1970. Glycolytic and gluconeogenic enzyme activities in the hereditary obese-hyperglycemic syndrome and in acquired obesity. Diabetologia. 6:313-316.

18. Belefiore, F., S. Iannello, A. M. Rabuazzod, and R. Campione. 1987. Metabolic effects of short-term fasting in obese hyperglycemic humans and mice. Int. J. Obesity. 11:631-646.

19. Coleman, D. L., and K. P. Hummel. 1967. Studies with the mutation, diabetes, in the mouse. Diabetologia. 3:238-248.

20. Stengard, J. H., H. U. Saarni, R. I. Karvonen, J. T. Lahtela, N. T. Karki, F Stenback, and E. A. Sotaniemi. 1987. Hepatic drug metabolism and the activities of NADPH generating enzymes and glucose-6-phosphatase in phenobarbitaltreated genetically obese (ob/ob) mice. Biomed. Pharmacother. 41:389-396.

21. Soll, A. H., C. R. Kahn, D. M. Neville, Jr., and J. Roth. 1980. Insulin receptor deficiency in genetic and acquired obesity. J. Clin. Invest. 56:769-780.

22. Chang, H. Y., and D. I. Schneider. 1970. Abnormality in hepatic enzyme activity during development of diabetes in genetically diabetic mice. Diabetolo gia. 6:274-278.

23. Tannti, J. F., T. Gremeaux, E. Brandenburg, E. Van Obberghen, and Y. L. Marchand-Brustel. 1986. Brown adipose tissue in lean and obese mice. Diabetes. 35:1243-1248.

24. Vicario, P., E. J. Brady, E. E. Slater, and R. Superstein. 1987. Insulin receptor tyrosine kinase activity in unaltered in ob/ob and $\mathrm{db} / \mathrm{db}$ mouse skeletal muscle membranes. Life Sci. 41:1233-1241.

25. Marchand-Brustel, Y. L., T. Gremeux, R. Ballotti, and E. Van Obberghen. 1985. Insulin receptor tyrosine kinase is defective in skeletal muscle of insulin-resistant obese mice. Nature (Lond.). 315:676-679.

26. Meyerovitch, J., J. M. Backer, and C. R. Kahn. 1989. Hepatic phosphotyrosine phosphatase activity and its alteration in diabetic rats. J. Clin. Invest. 84:976-983.

27. Ullrich, A., J. R. Bell, E. Y. Chen, R. Herrera, L. M. Petruzzelli, T. J. Dull, A. Gray, L. Coussens, Y. C. Liao, M. Tsubokawa, A. Mason, P. H. Seeburg, C. Grunfeld, O. M. Rosen, and J. Ramachandran. 1985. Human insulin receptor and its relationship to the tyrosine kinase family of oncogenes. Nature (Lond.). 313:756-761.

28. Kasuga, M., M. F. White, and C. R. Kahn. 1984. Phosphorylation of the insulin receptor in cultured hepatoma cells and in solubilized system. Methods Enzymol. 109:609-621.

29. Sparks, J. W., and D. L. Brautigan. 1985. Specificity of protein phosphotyrosine phosphatase. Comparison with mammaline alkaline phosphatase using polypeptide substrates. J. Biol. Chem. 260:2042-2045.

30. Shacter, E. 1984. Organic extraction of Pi with isolbutanol/toluene. Anal. Biochem. 138:416-420.

31. Desbuquois, B., and G. D. Aurbach. 1971. Use of polyethylene glycol to separate free and antibody-bond peptide hormones in radio immunoassays. $J$. Clin. Endocrinol. Metab. 33:732-738.

32. Stoop, S. D., G. Helinek, and H. L. Greene. 1982. More sensitive flameless atomic absorption analysis of vanadium in tissue and serum. Clin. Chem. 28:7982. 
33. Bradford, M. M. 1976. A rapid and sensitive method for the quantitation of microgram quantities of protein utilizing the principle of protein dye binding. Anal. Biochem. 72:248-254.

34. White, M. F., R. Maron, and C. R. Kahn. 1985. Insulin rapidly stimulates tyrosine phosphorylation of $\mathrm{M}_{\mathrm{r}}-185,000$ protein in intact cells. Nature (Lond.). 318:183-186.

35. Cohen, P. 1982. The role of protein phosphorylation in neural and hormonal control of cellular activity. Nature (Lond.). 296:613-620.

36. White, M. F., S. E. Shoelson, H. Keutmann, and C. R. Kahn. 1988. A cascade of tyrosine autophosphorylation in the $\beta$-subunit activates the phosphotransferase of the insulin receptor. J. Biol. Chem. 263:2969-2980.

37. Tornquist, H. E., M. W. Pierce, A. R. Frackelton, R. A. Nemenoff, and J. Avruch. 1987. Identification of insulin receptor tyrosine residues autophosphorylated in vitro. J. Biol. Chem. 262:10212-10219.

38. Lau, K. W. W., J. R. Farley, and D. J. Baylink. 1989. Phosphotyrosyl protein phosphatases. Biochem. J. 257:23-36.

39. Hunter, T. 1989. Protein-tyrosine phosphatase: the other side of the coin. Cell. 58:1013-1016.

40. Fukudo, S., S. Virnelli, C. Kuhn, C. Cochrane, M. Cochrane, M. Feinglos, and R. Surwit. 1989. Differential effects of cholinergic stimulation in glucose metabolism in diabetic and non-diabetic mice. Endocrinology. 124:1361. (Abstr.).

41. Rotenberg, S. A., and D. L. Brautigan. 1987. Membrane protein phosphotyrosine phosphatase in rabbit kidney. Biochem. J. 243:747-754.

42. Tonks, N. K., C. D. Diltz, and E. H. Fischer. 1988. Purification of the major protein-tyrosine-phosphatases of human placenta. J. Biol. Chem. 263:6722-6730.

43. Cushman, S. W., and L. J. Wardzala. 1980. Potential mechanism of insulin action on glucose transport in the isolated rat adipose cell. J. Biol. Chem. 255:4758-4762.
44. Graeme, R. G., J. Gordon, L. Walker, R. H. Michell, and G. Brown. 1986. Redistribution of protein kinase $\mathrm{C}$ during mitogenesis of human $\mathrm{B}$ lymphocytes. Biochem. Biophys. Res. Commun. 135:146-153.

45. Cooper, D. R., T. S. Konda, M. L. Standaert, J. S. Davis, R. J. Pollet, and R. V. Farese. 1987. Insulin increases membrane and cytosolic protein kinase $C$ activity in $\mathrm{BC}_{3} \mathrm{H}-1$ myocytes. J. Biol. Chem. 262:3633-3639.

46. Susuo, K., and T. Kono. 1980. Evidence that insulin causes translocation of glucose transport activity to the plasma membrane from an intracellular storage site. Proc. Natl. Acad. Sci. USA. 77:2452-2545.

47. Ingebritsen, T. S. 1989. Phosphotyrosyl-protein phosphatases. II. identification and characterization of two heat-stable protein inhibitors. J. Biol. Chem. 264:7754-7759.

48. Yang, S. D., J. S. Yu, J. S. Liu, T. C. Tzen, and J. K. Wang. 1987. The type I protein phosphatase activating factor $\mathrm{Fa}$ is a membrane associated protein $\mathrm{ki}$ nase in brain, liver, heart and muscles. Biochem. Biophys. Res. Commun. 142:38-46.

49. Meyerovitch, J., Y. Shechter, and S. Amir. 1989. Vanadate stimulate in vivo glucose uptake in brain and arrest food intake and body weight gain in rat. Physiol. Behavior. 45:1113-1116.

50. Strout, H. V., P. P. Vicario, R. Superstein, and E. E. Slater. 1989. The insulin-mimetic effect of vanadate is not correlated with insulin receptor tyrosine kinase activity nor phosphorylation in mouse diaphragm in vivo. Endocrinology. 124:1918-1924.

51. Hefetz, D., and Y. Zick. 1989. $\mathrm{H}_{2} \mathrm{O}_{2}$ potentiates phosphorylation of novel putative substrates for the insulin receptor kinase in intact Fao cells. J. Biol. Chem. 264:10126-10132.

52. Rossetti, L., and M. R. Laughlin. 1989. Correction of chronic hyperglycemia with vanadate, but not with phlorizin, normalize in vivo glycogen repletion and in vitro glycogen synthatase activity in diabetic skeletal muscle. $J$. Clin. Invest. 84:892-899. 